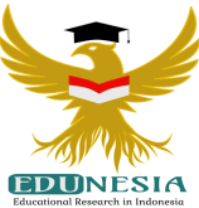

\title{
Penilaian Autentik Dalam Meningkatkan Hasil Belajar Fisika di SMAN 1 Pagaden
}

\author{
Dadang Suhardi \\ Pendidikan Fisika, SMAN 1 Pagaden, Indonesia. \\ Corresponding Email: dadangsuhardi86@gmail.com, Phone Number : 0822 xxxx xxxx
}

\section{Article History:}

Received: Sept 20, 2020

Revised: Okt 02, 2020

Accepted: Okt 03, 2020

Published: Jan 01, 2021

\section{Keywords:}

Authentic assessment, Learning outcomes, Physics

\section{Kata Kunci:}

Fisika, Hasil Belajar, Penilaian autentik.

\section{How to cite:}

Suhardi, D. (2021).

Penilaian Autentik Dalam

Meningkatkan Hasil

Belajar Fisika di SMAN 1

Pagaden. Edunesia : Jurnal

Ilmiah Pendidikan, 2 (1): 65-74

This is an open access article under the CC-BY-NC-ND

\begin{abstract}
Physics is one of the subjects that students consider difficult. This can be seen from the learning outcomes of students at SMAN 1 Pagaden Class X IPA 4, where the majority of students score below the KKM (minimum completeness criteria). Of the 36 students in class X IPA 4 in physics, only about 12 students got a complete score. Of course, this situation should get serious attention to improve student learning outcomes. One of the efforts made to improve learning outcomes is through authentic assessment. In this assessment, all student activities will be observed and rated according to their respective portions. This research is a descriptive qualitative study with a two-cycle model that is characteristic of Classroom Action Research. From the research results it was revealed that with authentic assessment of physics learning in Class X IPA 4 SMAN 1 Pagaden there was an increase in each cycle. In the first cycle, the students' average score on the skills aspect was around $71 \%$ and increased in the second cycle to $80 \%$. So that the use of authentic assessment is one of the references as an effort to improve student learning outcomes.
\end{abstract}

Abstrak: Fisika merupakan salah satu mata pelajaran yang dianggap sulit oleh siswa. Hal ini ini dapat terlihat dari hasil belajar siswa di SMAN 1 Pagaden Kelas X IPA 4 yang mayoritas siswa mendapatkan nilai di bawah KKM (kriteria ketuntasan minimum). Dari 36 siswa di kelas X IPA 4 dalam pelajaran fisika, hanya sekitar 12 siswa yang mendapatkan nilai tuntas. Tentu saja, keadaan ini harus mendapatkan perhatian serius untuk meningkatkan hasil belajar siswa. Salah satu upaya yang dilakukan untuk meningkatkan hasil belajar yaitu melalui penilaian autentik. Dalam penilaian ini, seluruh aktivitas siswa akan diamati dan diberi nilai sesuai dengan porsinya masing-masing. Penelitian ini bersifat kualitatif deskriptif dengan model dua siklus yang menjadi ciri khas dari Penelitian Tindakan Kelas. Dari hasil penelitian terungkap bahwa dengan penilaian autentik pada pembelajaran fisika di Kelas X IPA 4 SMAN 1 Pagaden terjadi peningkatan pada setiap siklusnya. Pada siklus pertama rata-rata siswa mendapatkan nilai pada aspek keterampilan sekitar $71 \%$ dan naik pada siklus kedua menjadi $80 \%$. Sehingga penggunaan penilaian autentik merupakan salah satu rujukan sebagai upaya untuk meningkatkan hasil belajar siswa. 


\section{A. Pendahuluan}

Dalam pelaksanaannya, pendidikan mengalami banyak perubahan baik secara kontekstual maupun metodologis. Pendidikan merupakan usaha yang dilakukan untuk mengubah seseorang dari tidak tahu menjadi tahu, dari pengetahuan ini diharapkan menjadi sebuah sikap yang reflektif, kritis, dan bertanggungjawab. Menyadari pentingnya pendidikan sebagai sebuah upaya untuk membentuk kerangka berpikir maka sudah sewajarnya sekolah sebagai sebuah lembaga pendidikan formal untuk melaksanakan kegiatan belajar mengajar yang akan menghasilkan peserta didik yang memiliki pola pikir sebagai seorang akademisi dengan sikap yang menjungjung tinggi nilai-nilai serta norma kemanusian. Secara ideal, konsep tersebut menjadi buku manual bagi guru untuk melaksanakan pembelajaran. Namun, dalam pelaksanaannya banyak kendala yang dihadapi oleh guru dalam mencapai Tujuan Pendidikan Nasional.

Dari penelitian Musdalifah (2013) menunjukan "rendahnya hasil belajar, permasalahan lain yang diperoleh di lapangan berdasarkan hasil wawancara pada salah seorang guru fisika di SMA Negeri 8 Palu adalah kurangnya konsentrasi siswa saat belajar sehingga sulit untuk memahami materi yang diberikan. Daftar nilai yang merupakan hasil belajar siswa semester ganjil di SMA Negeri 8 Palu tahun ajaran 2012/2013 menunjukkan bahwa prestasi belajar siswa fisika kelas X SMA negeri 8 Palu masih tergolong rendah".

Rendahnya ketercapaian hasil belajar ini sangat dipengaruhi oleh intake siswa, kompleksitas, serta sarana pendukung. Menyadari sarana pendukung di SMAN 1 Pagaden untuk melaksanakan pembelajaran fisika yang masih terbatas sangat berpengaruh terhadap proses belajar mengajar sehingga hasil yang dicapai kurang optimal. Dari 36 siswa di Kelas X IPA 4, hanya 12 siswa yang mendapatkan nilai tuntas pada pembelajaran fisika. Secara filosofis, materi dalam pembelajaran fisika yang banyak menguraikan hitungan dan teori menjadikan fisika sebagai salah satu mata pelajaran yang kurang populer dikalangan peserta didik. Dari data wawancara di Kelas X IPA 4 SMAN 1 Pagaden sekitar $72 \%$ siswa cenderung menghindari pelajaran fisika karena dianggap rumit dan membosankan.

Untuk mengubah sudut pandang tersebut maka harus ada sebuah inovasi dalam kegiatan belajar mengajar. Pola guru aktif harus diubah menjadi siswa aktif, mengikutsertakan siswa dalam kegiatan belajar mengajar dengan cara mengeksplor pikiran dan pengalamannya akan mengubah kecenderungan yang biasa terjadi dalam kegiatan belajar mengajar. Tentu saja untuk mengubah pola belajar dari guru aktif menjadi siswa aktif bukan suatu hal yang mudah, dibutuhkan pemahaman konsep yang baik dari siswa agar pelaksanaan kegiatan belajar mengajar tidak lagi didominasi oleh guru. Dalam suatu penelitian yang dilakukan oleh Rusilowati (2006) menyebutkan bahwa "hasil analisis menunjukkan bahwa secara umum siswa SMA di kota Semarang lemah dalam penguasaan konsep, kemampuan matematis, dan mengkonversi satuan. Siswa yang lemah dalam penguasaan konsep sebanyak 49,63\%. Siswa yang lemah dalam kemampuan matematis sebanyak $40,5 \%$ dan yang bermasalah dengan konversi satuan sebanyak $46,8 \% "$.

Kondisi yang sama persis seperti SMA di Semarang. Mayoritas siswa dalam belajar fisika kurang memahami konsep dengan baik, kemampuan siswa dalam bidang matematis menjadi hambatan untuk dapat memahami materi tentang fisika, dan hal yang paling substansi dalam pelajaran fisika adalah cara mengkonversi satuan tetapi yang dialami oleh siswa juga tidak dapat mengkonversi satuan dengan baik. Sehingga 
penelitian di atas sangat relevan dengan kondisi siswa di SMAN 1 Pagaden. Dari data hasil belajar yang menunjukan ketuntasan hanya sekitar 37,72\% siswa yang tuntas dalam pembelajaran fisika. Hasil lain mengenai kesulitan mempalajari fisika terdapat dalam penelitian Azizah dkk (2015), "siswa mengatakan fisika itu sulit disebabkan karena fisika terlalu banyak rumus (71\%) dan banyak konsep (25\%). Selain itu, beberapa siswa mengatakan merasa sulit mempelajari fisika karena fisika banyak rumusnya, guru terlalu cepat ketika menerangkan dan metode pembelajarannya membosankan".

Selain mengubah pada proses pembelajaran, hal lain yang dapat dilakukan untuk mengubah kondisi belajar yang menuntut siswa aktif adalah dengan cara melakukan penilaian autentik. Dalam penilaian autentik tidak hanya menilai sebuah produk tetapi juga menilai pada proses. Temuan pada penelitian yang dilakukan oleh Yuliana \& Alimufi (2015) menemukan "nilai ketuntasan tes hasil belajar siswa diperoleh dari lembar penilaian siswa meliputi penilaian aspek pengetahuan, aspek keterampilan, dan aspek sikap. Setelah penilaian autentik berbasis kinerja diterapkan, diketahui bahwa peningkatan hasil belajar siswa terendah pada aspek pengetahuan adalah sebesar $-0,11$, mengalami penurunan dari nilai 55 menjadi 50. Sedangkan peningkatan tertinggi adalah sebesar 0,67, yaitu meningkat dari nilai 55 menjadi 85. Rata-rata peningkatan hasil belajar siswa mencapai angka 0,33 dengan kriteria sedang". Aktivitas siswa selama belajar akan diamati dan diberikan penghargaan dalam nilai sehingga siswa akan lebih bersemangat dalam melaksanakan kegiatan belajar mengajar dan diharapkan akan berdampak pula pada hasil belajar siswa. Menurut (Musfiqon, 2016) menyatakan bahwa;

"Penilaian merupakan bagian yang tidak terpisahkan dalam proses pembelajaran. Penilaian harus bersifat komprehensif dan holistik yang mencakup semua aspek dari tujuan pembelajaran. Penilaian dilakukan secara berkesinambungan untuk memperoleh informasi pembelajaran. Dalam melakukan penilaian guru harus memegang teguh prinsip-prinsip dalam standar penilaian otentik yakni keeping track, Checking up, Finding out, Summing up. Penilaian otentik memiliki relavansi kuat terhadap pendekatan ilmiah dalam pembelajaran sesuai dengan tuntutan Kurikulum 2013. Guru bukan hanya dituntut untuk mengukur hasil kerja siswa tetapi juga proses belajar yang dilalui siswa. Diantara proses penilaian otentik ini dapat menggunakan berbagai jenis penilaian diantaranya adalah: 1) tes standart prestasi, 2) tes buatan guru, 3) catatan kegiatan, 4) catatan anekdot, 5) skala sikap, 6) catatan tindakan, 7) konsep pekerjaan, 8) tugas individu, 9) tugas kelompok atau kelas, 10) diskusi, 11) wawancara, 12) catatan pengamatan, 13) peta perilaku, 14) portofolio, 15) kuesioner, dan 16) pengukuran sosiometri. Penilaian Otentik mementingkan penilaian proses dan hasil sekaligus. Dengan demikian, seluruh tampilan siswa dalam rangkaian kegiatan pembelajaran dapat dinilai secara objektif, apa adanya, dan tidak semata-mata hanya berdasarkan hasil akhir (produk) saja. Buku "penilaian otentik dalam Pembelajaran Kurikulum 2013" ini wajib dimiliki oleh praktisi pendidikan untuk mengetahui dan melaksanakan penilaian dengan lebih baik".

Dari penelitan yang dilakukan Maruf \&Rahim (2013) menemukan kecenderungan bahwa "hasil belajar siswa pada penilaian non autentik meningkat 16,56 \% setelah mengunakan perangkat penilaian autentik, dimana salah satu siswa memberi kesan dengan penilaian autentik membuat rasa ingin tahu saya tinggi, sehingga rasa malas yang pernah ada dalam diri saya sekarang sudah lenyap, oleh karena itu penilaian autentik 
sangat baik bagi siswa terutama terhadap saya karena dapat meningkatkan mutu belajar untuk mencapai nilai yang semaksimal mungkin".

Dengan landasan penelitian terdahulu yang dikemukakan pada pembahasan sebelumnya menjadi rujukan logis untuk melakukan penelitian yang sama di SMAN 1 Pagaden agar hasil belajar siswa yang selama ini kurang memuaskan dapat ditingkatkan ketercapaiannya. Selama ini siswa memilih untuk menghindari pelajaran fisika sehingga penulis harus membuat skenario yang lain dalam upaya perbaikan hasil belajar pada pembelajaran fisika dengan menggunakan penilaian autentik. Bagi rekan guru fisika lainnya dapat diperoleh manfaat dari penelitian ini berupa bagaimana caranya meningkatkan hasil belajar dengan menerapkan penilaian autentik.

\section{B. Metode}

Penelitian ini bersifat kualitatif deskriptif dengan menggunakan dua siklus yang merupakan ciri khas dari Penelitian Tindakan Kelas. Data diperoleh melalui tes, wawancara, angket serta obeservasi. Untuk menguji penilaian autentik pada pembelajaran fisika di SMAN 1 Pagaden maka diambil sampel pada kelas X IPA 4. Pengambilan sampel ini dikarenakan jumlah populasi yang begitu besar, seluruh siswa SMAN 1 Pagaden berjumlah sekitar 1.242 siswa sehingga diambil sampel kelas X IPA 4 yang berjumlah 36 siswa. Dari statistik hasil belajar siswa pada pelajaran fisika di Kelas $X$ IPA 4 rata-rata siswanya mendapatkan hasil belajar di bawah KKM (kriteria ketuntasan minimum), hasil perhitungan antara intake siswa, kompleksitas, dan daya dukung maka KKM untuk pelajaran fisika kelas $X$ yaitu 70 .

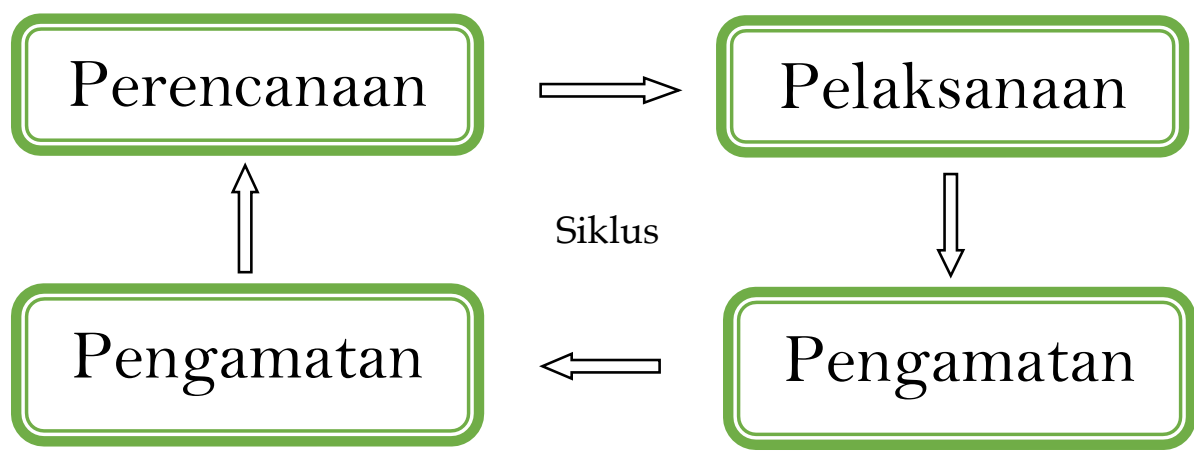

Gambar 1.

Siklus Penelitian Tindakan Kelas

Penelitian ini berlangsung dari bulan Juli hingga Oktober 2018 dengan melibatkan rekan sejawat sesama guru fisika. Untuk mendapatkan hasil penelitian berupa penilaian sikap digunakan insterumen berupa lembar observasi (angket), sedangkan untuk mendapatkan data mengenai penilaian kognitif digunakan instrument tes tulis, dan penilaian kinerja digunakan untuk mendapatkan data berupa nilai keterampilan. Ketiga aspek tersebut sangat penting untuk diamati dan dinilai karena dalam penilaian autentik tidak hanya menekankan pada hasil penilaian kognitif saja tetapi juga penilaian psikomotor dan afektif juga penting untuk diamati sehingga siswa akan lebih menunjukan kompetensinya dari awal hingga akhir pembelajaran. 


\section{Hasil dan Pembahasan}

Pada Penilaian autentik aspek yang diukur tidak hanya pada ranah kognitif. Semua aspek yang berkaitan dengan pembelajaran akan diamati dan dinilai. Ungkapan tersebut dikemukakan pada penelitian sebelumnya oleh Ermawati \& Hidayat (2017) "penilaian terhadap aspek pengetahuan, aspek sikap, maupun aspek keterampilan sama pentingnya. Bahkan, aspek sikap dan keterampilan memiliki peran penting untuk mengetahui kemampuan nyata siswa, bukan hanya penguasaan teori atau konsep semata". Penelitian ini bermaksud untuk meningkatkan hasil belajar siswa pada pembelajaran fisika, dari hasil tes yang dilakukan di Kelas X IPA 4 SMAN 1 Pagaden ternyata rata-rata siswa menunjukan nilai yang belum tuntas.

Tabel 1.

Hasil Belajar Siswa Dalam Pelajaran Fisika Sebelum Penerapan Penilaian Autentik

\begin{tabular}{|llcl|}
\hline No & $\begin{array}{l}\text { Ketercapaian } \\
\text { Hasil Belajar }\end{array}$ & $\begin{array}{l}\text { Jumlah } \\
\text { Siswa }\end{array}$ & Persentase \\
\hline 1 & Nilai 100 & 0 & 0 \\
\hline 2 & Nilai $80-90$ & 2 & 1,72 \\
\hline 3 & Nilai $70-80$ & 10 & 36 \\
\hline 4 & Nilai $<70$ & 24 & 62,01 \\
\hline & Jumlah & 36 & 100 \\
\hline
\end{tabular}

\section{Data: Hasil Pengamatan}

Dengan kondisi tersebut maka dirancang penelitian ini untuk meningkatkan hasil belajar siswa. Selama ini aktivitas siswa hanya mengukur kemampuan kognitif saja sehingga siswa tidak dilibatkan secara langsung. Minimnya keterlibatan siswa ini menyebabkan pembelajaran fisika menjadi tidak efektif. Oleh karena itu, penelitian ini dilakukan guna meningkatkan hasil belajar siswa melalui penilaian autentik. Dengan penilaian autentik maka seluruh aktivitas siswa akan diamati dan dinilai. Namun, sebelum melakukan penelitian ini maka pada tahap awal penelitian ini disusun sebuah perencanaan dengan membuat RPP (rencana pelaksanaan pembelajaran) dan kemudian menentukan tujuan serta indikatornya sebagai acuan untuk mengukur tingkat keberhasilan pembelajaran pada saat itu. Setelah menyiapkan RPP maka pada proses selanjutnya adalah menentukan KKM (kriteria ketuntasan minimum). Langkah selanjutnya adalah menerapkan pembelajaran fisika yang berbasis penilaian autentik.

\section{Siklus Pertama}

Seperti yang diuraikan sebelumnya bahwa Langkah awal sebelum melaksanakan pembelajaran berbasis penilaian autentik guru harus menentukan tujuan pembelajaran. Hal ini juga pernah diungkapkan (Sutama dkk, 2017) bahwa "hasil penelitian ini dapat dimaknai bahwa dalam menyusunan instrumen penilaian guru perlu mengetahui karakteristik apa saja yang menjadi tujuan dari sebuah penilaian yang akan dilakukan. Dari observasi yang dilakukan di SMA Negeri 2 Sukoharjo menunjukan bahwa dalam sebuah penyusunan instrumen penilaian autentik guru sudah melakukan langkahlangkah dalam menyusun instrumen penilaian yaitu dengan menetapkan aspek-aspek 
yang akan diteliti, merumuskan tujuan, merumuskan indikator berdasarkan kompetensi dasar yang ada dalam silabus, dan membuat kriteria ketuntasan minimal sebagai tolak ukur hasil penilaian".

Setelah tahap perencanaan sudah disusun dengan baik maka selanjutnya adalah tahap yang menjadi inti dari penelitian yaitu tahap pelaksanaan. Pada tahapan ini dimaksudkan untuk mencari kaitan antara penerapan penilaian autentik terhadap mutu pembelajaran fisika di SMAN 1 Pagaden di kelas X IPA 4. Setiap aktivitas diamati untuk mendapatkan data primer yang kemudian akan dibuat tabel persentase guna melihat tingkat keberhasilan dari penilaian autentik di kelas X IPA 4 SMAN 1 Pagaden. Berikut ini akan ditampilkan tabel mengenai persentase penilaian autentik.

Tabel 2

Hasil Belajar Dengan Penilaian Autentik Pada Siklus Pertama Di Kelas X IPA 4

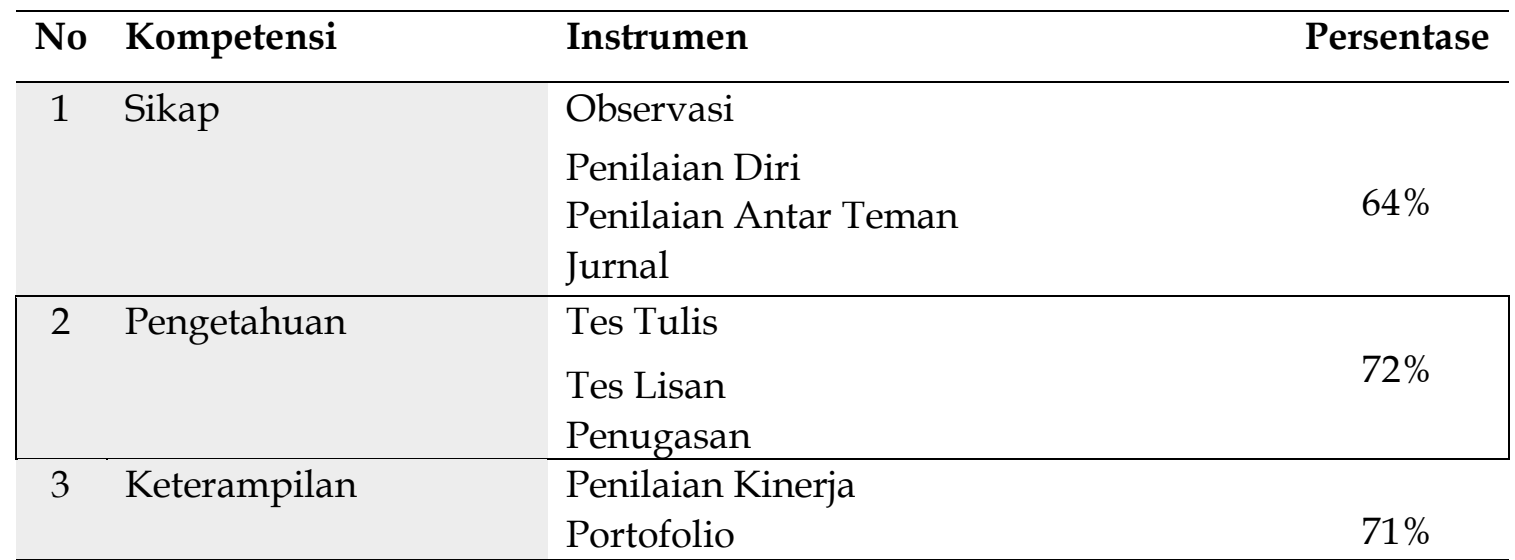

Data: Hasil Pengamatan

Dari tabel di atas diketahui bahwa pada saat kegiatan belajar mengajar mata pelajaran fisika di kelas X IPA 4 SMAN 1 Pagaden diperoleh persentase mengenai penilian sikap secara keseluruhan di siklus pertama sekitar 64\%. Peserta didik merasa setiap aktivitas selama kegiatan belajar mengajar berlangsung akan diberikan nilai sehingga sangat antusias dalam menanggapi materi yang disampaikan oleh guru. Secara rinci tentang penilaian sikap akan dipaparkan pada grafik instrumen penilaian sikap di bawah ini.
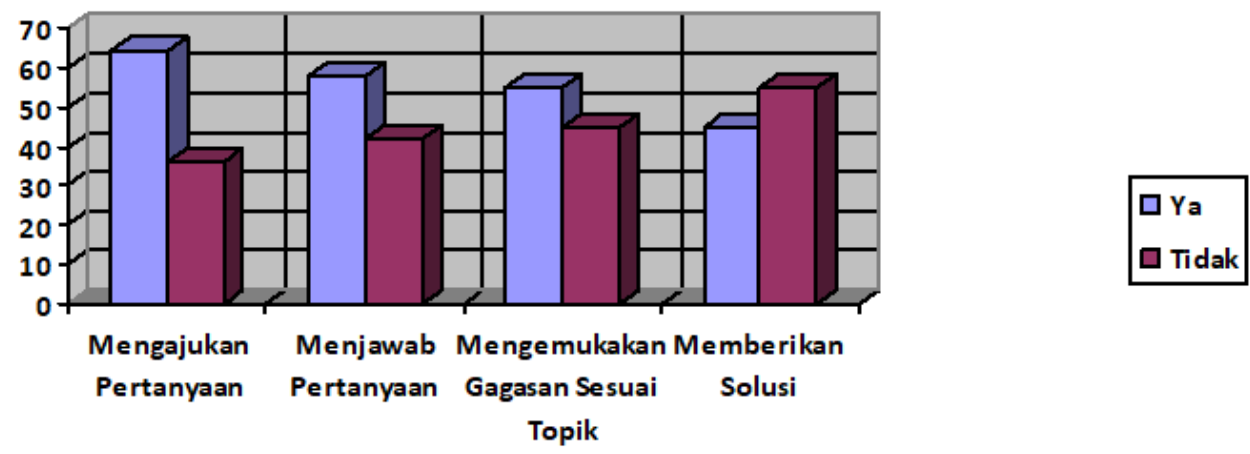

Gambar 2.

Instrumen Penilaian Sikap Pembelajaran Fisika Kelas X IPA 4 
Siswa yang mengajukan pertanyaan selama kegiatan belajar mengajar $55 \%$, dengan menerapkan penilaian autentik siswa menjadi lebih aktif dalam mengajukan pertanyaan serta menjawab pertanyaan karena dalam penilaian autentik penilaian bukan sekedar menjawab benar atau salah tetapi keaktifan belajar pun memiliki porsi yang sama dalam menentukan nilai akhir pada pelajaran fisika. Namun keakuratan jawaban serta jenis pertanyaan yang diajukan masih belum optimal. Siswa yang sudah memahami materi serta yang dapat memberikan solusi selama pembelajaran berlangsung angkanya masih rendah sekitar $45 \%$. Angka tersebut masih jauh bila dibandingkan dengan hasil penilitian yang dilakukan oleh (Suryani, 2016) "hasil uji coba pertama terhadap rubrik penilaian sikap ilmiah kelompok semua rubrik instrumen penilaian sikap ilmiah kelompok mempunyai persentasi lebih dari $75 \%$ sehingga dinyatakan layak digunakan tidak terdapat rubrik yang harus direvisi. Hal ini akan menjadi fokus pada siklus kedua untuk meningkatkan hasil dari penilaian sikap karena ketercapaian penilaian sikap harus mencapai 75\%".

Hasil dari tes tulis yang digunakan untuk mengukur kemampuan kognitif sudah termasuk kedalam kategori baik, yaitu sekitar 72\%. Dari hasil tersebut sudah sebagian besar siswa dalam pembelajaran ini mencapai KKM.

Dari aspek penilaian kinerja pada pembelajaran fisika di kelas X IPA 4 SMAN 1 Pagaden sudah tergolong baik. Pada kegiatan praktikum siswa terlihat lebih menikmati dan antusias dalam melakukan praktek. Aspek yang diamati pada rubrik kinerja ini meliputi tahap persiapan, selama kegiatan praktikum, dan kegiatan akhir praktikum. Rubrik penilian kinerja dapat dilihat dari grafik di bawah ini.

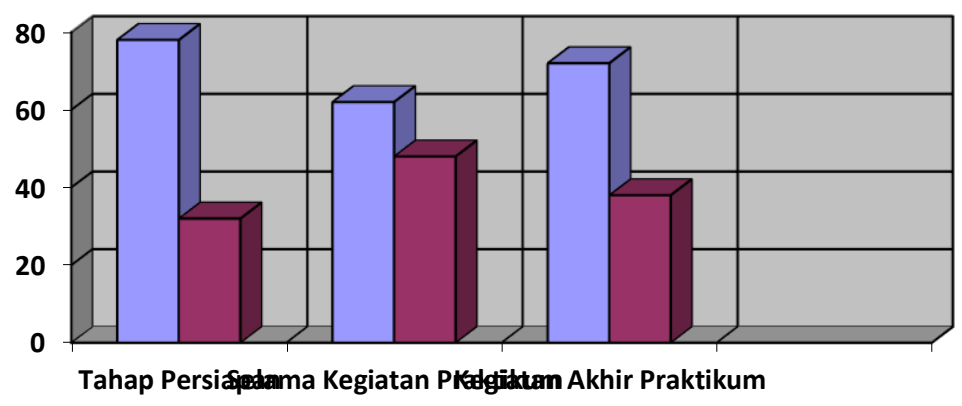

Gambar 3.

Penilaian Kinerja Pembelajaran Fisika Kelas X IPA 4

\section{Siklus Kedua}

Sebelum memulai kegiatan belajar mengajar dengan menggunakan penilaian autentik maka penulis menyusun sebuah perencanaan yang dijabarkan dalam RPP (rencana pelaksanaan pembelajaran). Dari RPP akan ditentukan sintake yang akan dilakukan dalam kegiatan belajar hingga menyusun instrumen evaluasi. Untuk evaluasi dibuat instrumen berupa; instrumen penilaian sikap, instrumen penilaian pengetahuan, dan instrumen penilaian keterampilan dengan mengacu pada tujuan pembelajaran.

Hasil penelitian yang dilakukan oleh Yuliana \& Alimufi (2015) "Instrumen authentic assessment berbasis kinerja dapat membuat aktivitas belajar siswa menjadi lebih baik, sehingga diperoleh hasil belajar siswa kelas XI SMA Negeri 1 Taman pada aspek 
pengetahuan dengan $\mathrm{n}$ gain sebesar 0,33 dengan kriteria peningkatan sedang, pada aspek keterampilan diperoleh rata-rata 3,37 dengan predikat A-, dan pada aspek sikap diperoleh rata-rata 3,12 dengan kategori baik".

Tabel 3.

Hasil Belajar Dengan Penilaian Autentik Pada Siklus Kedua Di Kelas X IPA 4

\begin{tabular}{|c|c|c|c|}
\hline No & Kompetensi & Instrumen & Persentase \\
\hline & Sikap & Observasi & \multirow[b]{2}{*}{$74 \%$} \\
\hline & & $\begin{array}{l}\text { Penilaian Diri } \\
\text { Penilaian Antar Teman } \\
\text { Jurnal }\end{array}$ & \\
\hline \multirow{2}{*}{\multicolumn{2}{|c|}{2 Pengetahuan }} & Tes Tulis & \multirow[b]{2}{*}{$78 \%$} \\
\hline & & $\begin{array}{l}\text { Tes Lisan } \\
\text { Penugasan }\end{array}$ & \\
\hline 3 & Keterampilan & $\begin{array}{l}\text { Penilaian Kinerja } \\
\text { Portofolio }\end{array}$ & $80 \%$ \\
\hline
\end{tabular}

Data: Hasil Pengamatan

Hampir sama dengan penelitian yang dilakukan oleh Yuliana dan Alimufi di SMAN 1 Taman bahwa peningkatan yang cukup signifikan terjadi pada ranah keterampilan bila dibandingkan dengan hasil penilaian dari aspek sikap dan aspek pengetahuan. Dari tabel di atas untuk hasil belajar yang berupa nilai keterampilan pada siklus pertama sebesar $71 \%$ tetapi pada siklus kedua naik menjadi $80 \%$.
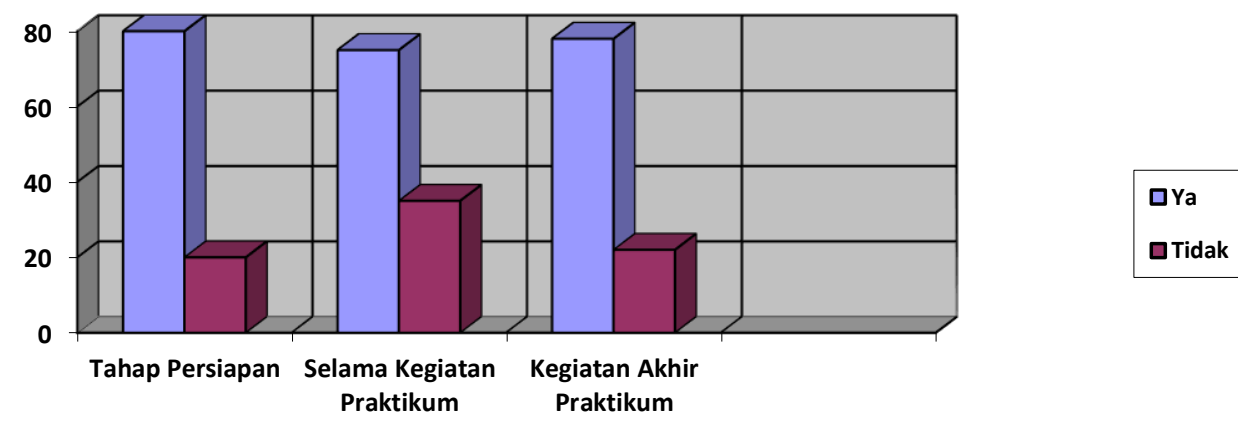

Gambar 4.

Penilaian Kinerja Pembelajaran Fisika Kelas X IPA 4

Pada aspek keterampilan dari siklus kedua siswa sudah mulai memahami bagaimana seharusnya mereka bekerja secara kolektif untuk memecahkan suatu permasalahan karena sudah memiliki pengalaman pada siklus pertama. Hasil yang cukup baik pada ketiga aspek bila dibandingkan guru mengajar dengan model konvensional. Dengan menggunakan penilaian autentik siswa memiliki kesempatan untuk berpartisipasi dalam kegiatan belajar mengajar. Hal ini yang membuat siswa menjadi ingin lebih aktif dan terlibat dalam kegiatan pembelajaran. Sebelumnya, dalam penelitian Gultom (2019) "semua proses analisis data telah dilaksanakan pada penelitian sehingga akhirnya diperoleh seperangkat instrumen penilaian autentik siswa kelas $X$ IPA pada 
pembelajaran fisika di SMA Negeri 4 Halmahera Utara yang valid secara empiris maupun secara konstruk. Instrumen penilaian autentik yang final ini terdiri dari 3 aspek baik kognitif, sikap dan psikomotorik yang dijabarkan dalam 58 butir instrument".

Pernyataan tersebut sekaligus menjawab dan mendukung hipotesa bahwa dengan penilaian autentik pada pembelajaran fisika di SMAN 1 Pagaden untuk meningkatkan hasil belajar dapat diterima dengan asumsi terjadi perbaikan hasil dari aspek sikap, aspek pengetahuan, dan aspek keterampilan. Pada Siklus pertama nilai dari aspek sikap rata-rata $64 \%$ naik menjadi $74 \%$ pada siklus kedua, aspek pengetahuan pada siklus pertama $72 \%$ naik menjadi $78 \%$, dan untuk aspek keterampilan pada siklus pertama sekitar $71 \%$ menjadi $80 \%$.

\section{Kesimpulan}

Tujuan awal dari penelitian ini bermaksud untuk meningkatkan hasil belajar pada aspek pengetahuan tetapi hasil yang diperoleh justru pada aspek keterampilan yang mendapatkan hasil yang lebih baik. Tetapi penerapan penilaian autentik di Kelas X IPA 4 SMAN 1 Pagaden dapat meningkatkan mutu pembelajaran terutama pada aspek keterampilan. Bila dibandingkan dengan ketiga aspek lainnya, aspek keterampilan pada siklus pertama maupun siklus kedua mendapatkan hasil yang lebih tinggi. Pada siklus pertama nilai keterampilan siswa sekitar $71 \%$ naik menjadi $80 \%$. Sehingga penilaian autentik sangat baik untuk meningkatkan keterampilan siswa karena adanya keterlibatan siswa dalam pembelajaran.

\section{Daftar Pustaka}

Azizah, R., Yuliati, L., \& Latifah, E. (2015). Kesulitan pemecahan masalah fisika pada siswa SMA. Jurnal penelitian fisika dan aplikasinya (JPFA), 5(2), 44-50.

Ermawati, S., \& Hidayat, T. (2017). Penilaian Autentik dan Relevansinya dengan Kualitas Hasil Pembelajaran (Persepsi Dosen dan Mahasiswa IKIP PGRI Bojonegoro). Jurnal Pendidikan Ilmu Sosial, 27(1), 92-103.

Gultom, Y. (2019). Pengembangan Instrumen Penilaian Autentik Pada Pembelajaran Teks Drama Untuk Siswa Kelas VIII SMP Negeri 6 Tebingtinggi (Doctoral dissertation, Universitas Negeri Medan).

Rusilowati, A. (2006). Profil kesulitan belajar fisika pokok bahasan kelistrikan siswa SMA di kota Semarang. Jurnal Pendidikan Fisika Indonesia, 4(2).

Musfiqon, H.M. (2016). Penilaian Otentik dalam Pembelajaran Kurikulum 2013. Sidoarjo: Nizamia Learning Center.

Maruf, M., \& Rahim, A. L. (2013). Pengembangan Perangkat Penilaian Autentik Dalam Pembelajaran Fisika Untuk Meningkatkan Motivasi, Partisipasi Dan Hasil Belajar Fisika Siswa Kelas X SMA Negeri 1 Pangkajene. Jurnal Pendidikan Fisika, 1(3), 252263. 
Musdalifah, N. (2013). Penerapan Pendekatan Kontekstual Berbasis REACT Untuk Meningkatkan Hasil Belajar Fisika Pada Siswa Kelas X SMA Negeri 8 Palu. JPFT (Jurnal Pendidikan Fisika Tadulako Online), 1(2), 55-60.

Yuliana, P. N., \& Alimufi, A. (2015). Pengembangan Instrumen Authentic Assessment Berbasis Kinerja dalam Pembelajaran Fisika pada Sub Pokok Bahasan Titik Berat Siswa Kelas XI SMA Negeri 1 Taman. Jurnal Inovasi Pendidikan Fisika (JIPF), 4(01), 47-52.

Suryani, I. (2016). Pengembangan Instrumen Penilaian Sikap Ilmiah pada Pembelajaran dengan Model Latihan Penelitian di Sekolah Dasar. PEDADIDAKTIKA: Jurnal Ilmiah Pendidikan Guru Sekolah Dasar, 3(2), 217-227.

Sutama, S., Sandy, G. A., \& Fuadi, D. (2017). Pengelolaan penilaian autentik kurikulum 2013 mata pelajaran matematika di SMA. Manajemen Pendidikan, 12(1), 105-114.

https:// doi.org/10.23917/jmp.v12i1.2967. 